\title{
Capital Structure Decision and Firm's Life Cycle-A Study on Non-Financial Sector of Pakistan
}

\footnotetext{
Sonia Zafar', Abdul Rahman², M. Faisal Rizwan², Muhammad Khalid Sohail ${ }^{3}$

${ }^{1}$ MS Scholar PMAS Arid Agriculture University Rawalpindi

${ }^{2}$ Associate Professor, Faculty of Management Sciences, International Islamic University, Islamabad ${ }^{2}$ Assistant Professor, Faculty of Management Sciences, International Islamic University, Islamabad ${ }^{3}$ Assistant Professor, Department of Management Sciences, COMSATS Institute of Information Technology, Islamabad
}

\section{A B S T R A C T}

The basic aim of this study is to distinguish the ratio of capital structure at different life cycle stages of a firm. Literature is rich in discussing the determinants of capital structure and its influence on the performance of a firm. However; the association of capital structure decision with respect to the life cycle stages is less investigated especially in the emerging economies. Therefore, in order to investigate the choice of leverage ratio during a firm's life cycle, 107 firms from the non-financial sector of Pakistan Stock Exchange for the period of ten years i.e. 2004- 2013 are selected. A deterministic approach is used to classify the life cycle stages as presented by Miller and Friesmen (1984). Panel data methodology is used to analyze the capital structure decision with respect to firm's life cycle. The results indicate that the leverage of a firm has a significant relation with the age of the firm, especially for the older firms. It will have a practical implication for the policy makers to focus on the easy availability of finance at younger stages of a firm as they feel financial constraints during their early life cycle.

KEYWORDS: Capital structure, determinants of capital structure, life cycle stages

\section{INTRODUCTION}

Capital structure theories date back to about more than half a century ago. Since then it's a hot topic among many scholars to define the optimal capital structure of a firm, at which it can maximize their value. According to a research by Farooq et al. (2013), studying capital structure is important as it plays a critical role in influencing the firm's

\section{Address of Correspondence}

Sonia Zafar

sonia275@live.com

\section{Article info}

Received July 16, 2016

Accepted Dec 09,2016

Published Dec 26,2016 
financial performance, its sustainability, and the potential development. Many factors have been identified that have a strong influence on the capital structure decision. However; no one can still clearly discuss the optimal capital structure of a firm. There are several factors that determine the capital structure of a firm e.g. Size, age, growth opportunities, accessibility of cash, the the presence of developed financial institutions in the economy, the reputation and creditworthiness of firms for the provision of loans, availability of tangible assets to be collateralized against the loan for security etc. These determinants are almost

Similar across all nations (G-7 nations) as suggested by Rajan and Zingales (1995), but there lies a limited scope for the theoretical underpinnings. Therefore; we can conclude that results cannot be generalized all around the world due to distinctive characteristics of the developed and the developing economies. The firm adjusts their capital structure according to their settings in which they are operating in order to increase the performance of the firm. Because the major focus always has been on the increasing performance of the firm. Due to this reason, the firms do not keep their capital structure static during their entire life cycle, rather, they do make changes as per need or requirement.

Management studies show us that almost every organization passes through some stages during its entire life cycle. All these stages have different characteristics that symbolize a particular stage. The birth stage is characterized by novelty, creativity, exploring and obtaining of resources like technological, financial, knowledge, human resources etc. Growth stage refers to the exploitation of resources to get the best of those resources. Maturity stage focuses on the stability of the organization in form of rules regulations, productivity, efficiency, and effectiveness. Here a need arises to decentralize the organizational structure in order to avoid over-bureaucratic structure of the organization. Then comes the decline stage where firms maintain to re-invent themselves in form of expansion or bringing new ideas and bringing innovation to the organization (Quinn and Cameron, 1983).

The basic purpose of this research is to explore the determinants of capital structure of the firms as it progresses through different phases during the entire course of 
a firm's life cycle, so as to examine the increasing or decreasing trend of leverage in relation to the pecking order theory. The key objectives are to analyze the capital structure decision at different stages of firm's life cycle, to analyze the determinants of capital structure in Pakistani non-financial firms at different stages and to analyze the determinants of capital structure in Pakistani non-financial firms in different industries.

As the company moves from one stage to another, the capital structure automatically needs changes; reason being that the goals and objectives of the firm's changes. Therefore, a need is felt to have an in-depth investigation about the financing patterns of firms; so as to make available finance at that phase, at which the firm is facing the financing constraints. Even though the recent attention on this topic has been paid, however; the data is rather limited regarding the financing pattern of firms in relation to their life cycle stages (Gregory et al. 2005). Here an attempt is made to discover the leverage ratio at different stages.

\section{LITERATURE REVIEW}

The capital structure of a firm has been a puzzle for more than half a century. How firms opt for the capital structure is still a mystery in different settings. Many theories have been put forward that forms the foundation of Capital Structure Decision. These theories have been tested under different settings, however; contrasting results are obtained. Reason being, there have been different factors that are affecting the decision of the capital structure. And the firm does not always follow the same specific order due to different institutional and environmental factors. As the literature is rich with the vast determining factors of the capital structure, all playing a vital part in determining the overall structure of capital e.g. different economies (emerging or developed), institutions, information asymmetries, size, growth opportunities, the tangibility of assets, profitability etc. Nearly all studies agree on the above-mentioned determinants along with the institutional context and industry affiliations in relation to the financing patterns of a firm.

Rocca and Rocca (2009) conducted the study in the Italian firms and found that the economy where the financial institutions are well developed, debt is considered as an important component of the capital structure in their early phases of the life cycle stages. 
As the firm moves towards the maturity phase, the profitability and growth opportunities are well enough to substitute the debt by their retained earnings and thus the capital structure is re-balanced. Moreover, pecking-order has a high application for those firms that have consolidated the business.

Peterson and Rajan (1994) also found that young firms rely mostly on the loans taken from family and friends. And then move towards bank loans. This debt is a major constituent of capital structure in their younger phase. Moreover, in their early years of developing business, a bank loan is a major incremental source of funds while family loans decreasing as a firm moves forward. Then, after some while when a firm has established itself well, it re-injects the self-generated financial resources and the level of debt decreases. These results have also been reported by Robb (2002) that younger firms make more use of external debt in contrast to older firms.

Michaelas et al. (1999) considered small firms in the UK in order to test several hypotheses with an aim to investigate the capital structure choice for small and medium business enterprises. The results suggested that the younger firms are more inclined towards the external debt in comparison to the older firms that are much profitable and can finance their operations utilizing the retained earnings and their accumulated internal sources. This indicated the negative relationship between the age of firms and their debt level. The results indicated a positive relation between asset structure and growth opportunities and leverage. However; a negative relation is found between age and profitability with leverage. Peterson and Rajan (1994) showed that leverage tends to decrease with age but tend to increase the size.

Contrasting results have been found in literature in relation to leverage and age. Williams (2010) deeply investigated the Jamaican economy with an aim to determine the financing patterns of the family-owned enterprises in the industrial sector. The objective of this research was to test the pecking order theory and the financial growth model in the Jamaican economy. The results certify that the start-ups use the internal sources first and as they grow larger and older, they move towards the external financing for their growth and survival function. The major reason behind following this order is that the external financing is not easily available to starting firms due to lack of information transparency 
and Government competing with the private firms for the same credit. Berger and Udell (1998) also suggested that the mature firms use more debt than the younger firms. This financing is mostly available from the financing institutions. Romano et al. (2001) found a significant relationship between the age of the firm and its effect on the financing decision by the owner. A study conducted by Walker (1989) also suggested that small firms change the composition of their financing as they progress through various stages of development. At maturity level, they were able to operate in the wider financial market. A study in China by Chen and Strange (2006), measured the age of a firm by the number of years, a firm is listed on the stock exchange. The results indicated that firms that are listed on the stock exchange for a longer number of years have more access to the debt due to the reduced information asymmetries.

According to Carey et al. (1993) and Helwege \& Liang (1996), the younger firms had financing pattern comprising of insiders funds and venture capital. Thus; according to them, small firms prefer the equity before the issuance of debt. It suggests the preference of debt in the later stages of the life cycle. Because as the firms mature, the firm has obtained a higher level of tangible assets that can be collateralized. Moreover; the firm has also built a reputation in the industry so information becomes less opaque and access to the financial market is easy so mature firms can have more debt, (Chittenden et al. 1996; Berger and Udell, 1998). Based on the above discussion, following hypothesis is made,

\section{H-1: Leverage increases with the life cycle of the firm.}

There are a large number of factors affecting the financing patterns of a firm. Capital structure decision during different stages is influenced by different determinants. Some are more influencing at one point in time than the other, Rocca and Rocca (2009). Thus, it is hypothesized that:

\section{H-2: Capital structure determinants differ across different lifecycle stages.}

Firms present in a particular industry tend to adopt almost similar financing patterns due to similar prevailing conditions (Cassar and Holmes, 2003). Hall et al. (2000) also point out the presence of inter-industry differences in financial structure. Thus, it is hypothesized that; 


\section{H-3: Capital structure determinants differ across different industries.}

\section{RESEARCH METHODOLOGY}

There exist many businesses that share the same phase of the life cycle. These phases of life cycle have a strong influence on their capital structure decision. These businesses fall into the category of either financial or non-financial sector which together comprises the stock exchange. The data is collected for the 107 firms in non-financial sectors of Pakistan for ten years i.e. from 2004-2013. Only those firms are selected for the study whose complete data is available and who remained listed in KSE throughout the study period. The firms with missing data are deleted from the sample. However; based on the similar operations, characteristics and their alike nature, these sectors have been classified into seven sectors as shown in table 3.1 presented below.

Table 3.1: Number of firms in non-financial sector

\begin{tabular}{|c|l|c|}
\hline Sr. No & \multicolumn{1}{|c|}{ Sectors } & No. of firms \\
\hline 1 & Energy Sector & 16 \\
\hline 2 & Chemicals and Pharmaceuticals & 16 \\
\hline 3 & Engineering Sector & 18 \\
\hline 4 & Electronics and General Industries & 23 \\
\hline 5 & Food and Beverages & 13 \\
\hline 6 & Personal goods (Textile) & 5 \\
\hline 7 & Miscellaneous & 107 \\
\hline 8 & Total & \\
\hline
\end{tabular}

For the purpose of classification of stages, following Rocca and Rocca (2009), initially, it was proposed to cater three stages into the analysis i.e. birth, growth and maturity. But the numbers of firms that are listed in the last six years are quite a few and for most of them, the availability of data is another issue that can't be ignored. Thus, the birth stage is added to the growth stage and named as the younger stage in order to make a relative sense for the mature stage. Two stages have also been used by Robb (2002) which includes younger and mature stages. The financial statements are collected from the respective company websites to get the in-depth knowledge of their operations. The 
final sample comprises of 107 firms. Out of which 85 belongs to the mature stage and 22 belongs to the younger stage.

Panel data methodology is used to test the above-stated hypothesis. Furthermore; unbalanced panel data is catered in the study, as the year of incorporation is different for different firms (especially for the younger stage) and their data availability depends on it. The relevant proxies of different variables i.e. the measurement and its explanation is presented in the following table 3.2

Table 3.2: Measurement of different variables

\begin{tabular}{|c|c|c|c|c|c|}
\hline $\begin{array}{l}\text { Sr. } \\
\#\end{array}$ & Variable & $\begin{array}{l}\text { Abbre } \\
\text { viation }\end{array}$ & $\begin{array}{l}\text { Unit of } \\
\text { Measurement }\end{array}$ & Measurement & References \\
\hline 1 & Leverage & Lev & Ratio & Total debt / total assets & Shah and Hijazi (2007) \\
\hline 2 & Age & Age & $\log$ & $\begin{array}{l}\text { Log of Number of years that a } \\
\text { firm has started its operation }\end{array}$ & Williams (2010) \\
\hline 3 & $\begin{array}{l}\text { Growth } \\
\text { Opportunity }\end{array}$ & GO & Ratio & $\begin{array}{l}\text { Industry weighted sales } \\
\text { growth }\end{array}$ & $\begin{array}{l}\text { Rocca and Rocca } \\
(2009)\end{array}$ \\
\hline 4 & Profitability & Prof & Ratio & $\begin{array}{l}\text { Earnings before interest and } \\
\text { taxes (EBIT) to total assets }\end{array}$ & Javaid and Imad (2012) \\
\hline 5 & Size & Size & $\log$ & $\begin{array}{l}\text { Log of the total assets of the } \\
\text { company }\end{array}$ & $\begin{array}{l}\text { Fattouh et al. (2008) } \\
\text { and Sogorb-Mira (2005) }\end{array}$ \\
\hline 6 & $\begin{array}{l}\text { Tangibility } \\
\text { Of Assets }\end{array}$ & ToA & Ratio & $\begin{array}{l}\text { The ratio of property, plant, } \\
\text { and equipment(i.e. fixed } \\
\text { assets) to total assets }\end{array}$ & $\begin{array}{l}\text { Rocca and Rocca } \\
(2009)\end{array}$ \\
\hline 7 & $\begin{array}{l}\text { Institutional } \\
\text { Shareholdi } \\
\text { ng }\end{array}$ & $\begin{array}{l}\text { INSTS } \\
\mathrm{H}\end{array}$ & Percentage & $\begin{array}{l}\text { the percentage of shares held } \\
\text { by the institutions }\end{array}$ & Hassan and Butt (2009) \\
\hline 8 & $\begin{array}{l}\text { Managerial } \\
\text { Shareholdi } \\
\text { ng }\end{array}$ & $\begin{array}{l}\text { MANG } \\
\text { SH }\end{array}$ & Percentage & $\begin{array}{l}\text { as a percentage of shares } \\
\text { held by the members of the } \\
\text { board }\end{array}$ & Hassan and Butt (2009) \\
\hline
\end{tabular}

Miller and Freismen (1984) model was followed in our study i.e. a firm with six years belongs to the birth stage, next ten years are of growth and above that are the mature firms. However; the number of firms in the birth stage is relatively fewer so it is combined with the growth stage i.e. firms for sixteen years comprises of the younger stage and above that belongs to the maturity stage. This criterion was also used by the 
Evans (1987); Yan (2006) and Bulan \& Yan (2009).

Panel data methodology is used in the current study. Three effects of panel data (common effect, fixed effect, and random effect) are applied. The general form of the equation to measure the leverage ratio at different phase is as follows:

$$
L e v_{i t}=\beta_{0}+\beta_{1}(A g B)_{i t}+\mu_{i t}
$$

Following equation is used to analyze the determinants of Capital Structure at different phases during a life cycle and on sectoral basis,

$$
\begin{gathered}
\operatorname{Lev}_{\text {it }}=\beta_{o}+\beta_{1}(\text { Age })_{\text {it }}+\beta_{2}(\text { Prof })_{\text {it }}+\beta_{3}(\text { size })_{\text {it }}+\beta_{4}(\text { ToA })_{\text {it }}+\beta_{5}(\text { INSTSH })_{\text {it }} \\
+\beta_{6}(\text { MANGSH })_{\text {it }}+\beta_{7}(G O)_{\text {it }}+\mu_{\text {it }}
\end{gathered}
$$

The dependent variable is Leverage (Lev) while independent variables used in the study are Age (Age), Profitability (Prof), Size (size), Tangibility of Assets (ToA), growth opportunities (GO) and Ownership Structure includes institutional shareholding (INSTSH) and managerial shareholding (MANGSH). $\mu$ term present in the equation refers to the error and subscripts (it) in the equation depicts the cross-sectional and timeseries variation.

\section{RESULTS AND DISCUSSION}

The descriptive statistics of various variables for all firms is presented in the following table 4.1. It shows that the age can have a maximum value of a log of 4.35 years having a deviation of 0.81 points. The Growth Opportunity of Pakistani firms as in the non-financial sector are about 24 points with a deviation of 35 points. The institutional and managerial shareholdings can hold a minimum of zero and maximum of 69 percent and 95 percent respectively. The mean value of the Leverage shows that most firms in the non-financial sector have 58 percent debt in their capital structure but this value can deviate from the mean up to 23 percent. Average Profitability of the firms is almost same to that of standard deviation. Firms in the non-financial sector also incur a loss as shown by the negative value of earnings. The tangible assets that firm can collateralize for obtaining the loan are almost half of the total assets. The firms belong to 
different sectors and due to differences in the industrial characteristics, policies and their strategies, the results are heterogeneous having a relatively high standard deviation.

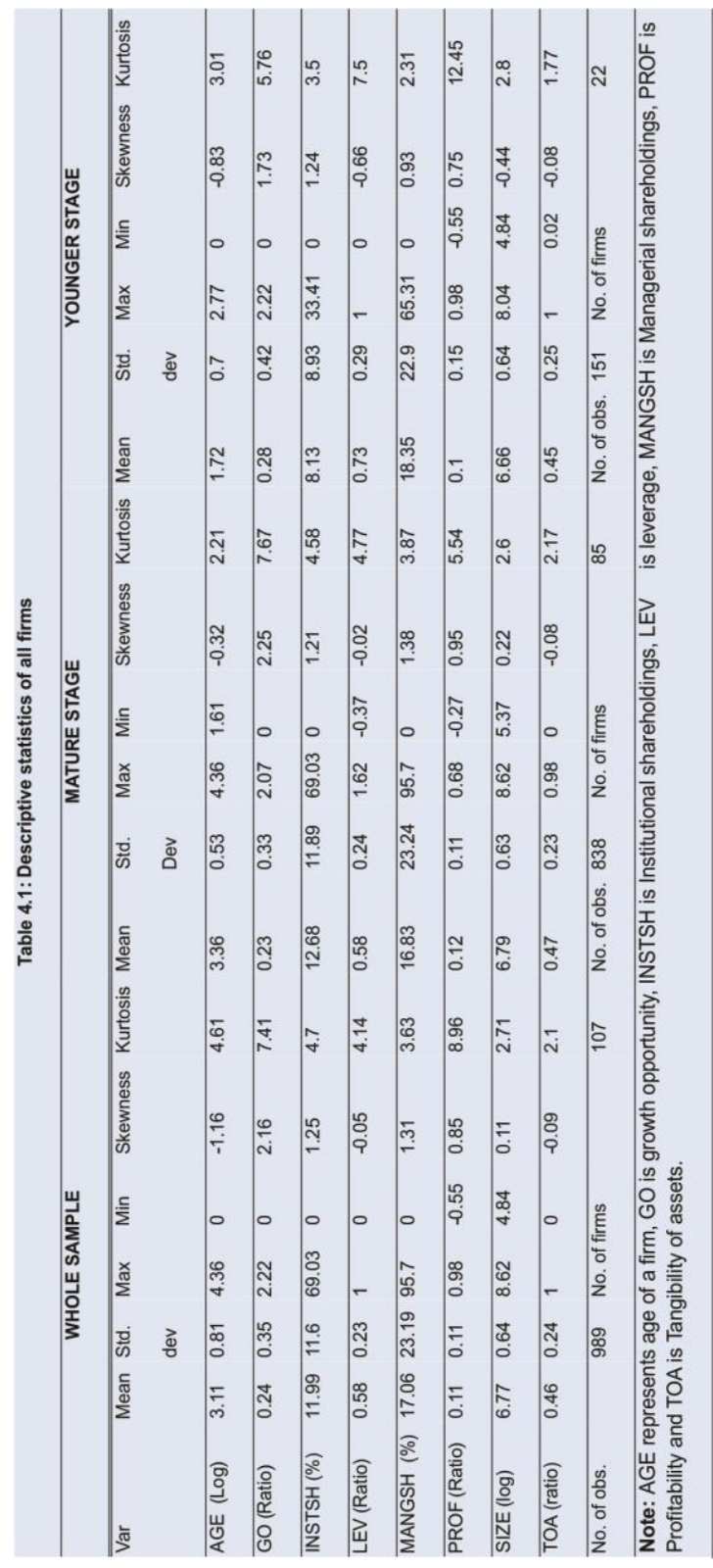

While comparing that of mature and growth stage firms, we can see that the log of age in maturity stage is almost double to that of the growth stage. The minimum and maximum values for the log of age in growth stage are zero and 2.772 respectively while those in the maturity stage are 1.609 and 4.356 .

The minimum growth opportunity $(\mathrm{GO})$ is zero for the growth firms while maximum goes to 2.22 with a mean of 28 percent and deviation of 42 percent. However; for mature firms, the minimum growth opportunity is zero with a maximum value of 2.06 . The deviation is lower in comparison to that of the growth firms. From here, we can conclude that the younger firms have more growth opportunity with high deviation. The GO can go about 2.245 sideways and height of 7.674 for maturity stage.

The institutional shareholdings in that of the mature firms grow by a larger percentage and have a maximum of 69 percent and that in the younger firms are 33 percent. The minimum shareholdings are zero. Similarly, the managerial shareholdings also go to the maximum range of 95 percent in mature firms and younger firms can go 
up-to-the maximum value of 65 percent.

The profitability as measured by the earning of the firm is greater for those of the maturity firms. And less for those of the younger firms; reason being that they have established over time and are able to generate greater profits. However; the minimum value of profitability can also go negative showing the loss for the company in both maturity as well as the younger stage.

The leverage in the mature firms is lower as compared to the leverage in the younger firms as clearly indicated by their mean value i.e. the mean value is 73 percent in younger firms and 57 percent of mature firms. The deviation is also higher for the younger firms.

The size of the firms is almost similar in both of the groups with a little difference between them. While focusing on the tangible assets, it can be concluded that as the firms move towards the maturity phase, the tangibility of assets increases in comparison to that of the younger firms. The tangible assets can be collateralized by the firms for obtaining debt. The height of ToA is more for the maturity stage.

Table 4.2 presents the Correlation matrix for variables in order to analyze the association between leverage and its determinants.

Table 4.2 Correlation among variables

\begin{tabular}{lllllllll}
\hline Variables & Age & G O & INSTSH & Lev & MANGSH & Prof & Size & ToA \\
\hline Age & 1 & & & & & & & \\
\hline G O & 0.029 & 1 & & & & & & \\
\hline INSTSH & 0.116 & 0.136 & 1 & & & & & \\
\hline Lev & -0.364 & -0.034 & -0.094 & 1 & & & & \\
\hline MANGSH & -0.030 & -0.144 & -0.177 & 0.132 & 1 & & & \\
\hline Prof & 0.085 & 0.105 & -0.032 & -0.425 & -0.088 & 1 & & \\
\hline Size & 0.090 & 0.208 & 0.064 & 0.020 & -0.332 & 0.045 & 1 & \\
\hline ToA & -0.202 & -0.085 & -0.136 & 0.171 & 0.184 & -0.201 & 0.028 & 1 \\
\hline
\end{tabular}

To test the co-alignment between leverage and its determinants, it is considered important to examine the independent relationships and associations among all variables. GO and age shows a positive relation between them. Tangibility, managerial 
shareholdings and size are positively related to the leverage. Which shows an increase in these variables will allow the firm to take more debt into account whereas; growth opportunity has a negative relation with leverage. This can be explained that if a firm has a growth opportunity, it lowers the willingness of a firm to have debt in their capital structure. Moreover, a profitable firm uses the retained earnings instead of opting for the debt. The results are also in accordance with the pecking order theory. Institutional shareholding is also negatively correlated to the leverage. For all the correlations discussed, it is seen that there exists a weak correlation for all the variables so it is also proved that there exists no multi-co-linearity among all variables.

This section highlights the regression results of the panel data methodology for the estimation of the developed hypothesis. The results of the panel data analysis are presented in the appendix (Table 4.7). Likelihood and Hausman test are used as criteria for selecting the fixed and random effect. As the p-value is found to be low than 0.05 fixed effect model is found to be appropriate. However; by applying the common coefficient model following results are obtained.

The general effect of leverage has been computed with the age factor to determine the significance level. Following is the table 4.3 that shows the whole sample leverage relation with age of firm. The coefficient sign indicated a negative relation with that of leverage thus highlighting the fact that as the age of firm increases, the leverage decreases. F statistics show the overall significance of the model.

Table 4.3: Leverage and Age

\begin{tabular}{lllll}
\hline Variable & Coefficient & Std. Error & t-Statistic & Prob. \\
\hline C & 0.977 & 0.030 & 32.727 & 0.000 \\
\hline AGE & -0.114 & 0.009 & -12.297 & 0.000 \\
\hline R-squared & 0.133 & Adjusted R-squared & & 0.132 \\
\hline F-statistic & 151.214 & Prob (F-statistic) & & 0.000 \\
\hline
\end{tabular}

The empirical results of the whole sample, maturity phase, and younger phase have been computed in table 4.4

As shown in the results; age, managerial shareholdings, and profitability are negatively related to leverage and growth opportunity, institutional shareholdings, size and 
tangibility of assets are positively related to leverage for the whole sample. We can say that as the firms grow older, the leverage ratio decreases. Robb (2002) has reported his findings suggesting that the firms at the younger stage are heavily financed by the external funds as the profitability is usually low. Therefore, they rely on debt but as they grow older more and more earnings are generated and the companies can rely on retained earnings and equity to finance their projects (Peterson and Rajan;1994). Growth opportunities for a firm are positively related to the leverage of a firm but this relationship is statistically insignificant. The empirical evidence is provided by the work of Rocca and Rocca (2009). When the numbers of shares held by the institutions are increased, the creditworthiness increases and more firms are willing to lend them loans; therefore, the leverage shows a positive relation with the institutional shareholdings. But this relationship is also statistically insignificant. The same results i.e. positive and insignificant results have been reported by Hassan and Butt (2009). The explanation as provided by the scholars indicates that the corporate governance is now at the infancy stage and needs to be focused upon. Especially in a country like Pakistan where most of the firms are family owned and are being run by the owners for years. Thus any change in the policies that is not in line with the history of a firm needs a considerable time to be acted upon. On the other hand, the managerial shareholdings refer to the shares that are held by the board of members including directors, executives etc. When the directors hold more and more of the shares of any firm; they prefer to avoid leverage because of the increased chances of the bankruptcy. Therefore, in order to avoid default by obtaining an excessive loan, managers prefer to lower the debt ratio. Thus, the whole sample shows a negative relation with the leverage as indicated by Hassan and Butt (2009). However; the results are statistically insignificant in our studies.

According to pecking order theory, the firms prefer to finance their projects from the internally generated funds that they have gathered in years. After exhausting those funds, the firm moves towards the debt as their second choice. And the third option left is the equity. As per this theory, when a firm has increased its profitability, it lowers its leverage due to the rebalancing of the capital structure. Thus; the increased profitability shows a negative sign with leverage indicating that the firms with increasing profitability 
tend to decrease its leverage ratio in their capital structure, (Hassan and Butt, 2009). This relationship is statistically significant.

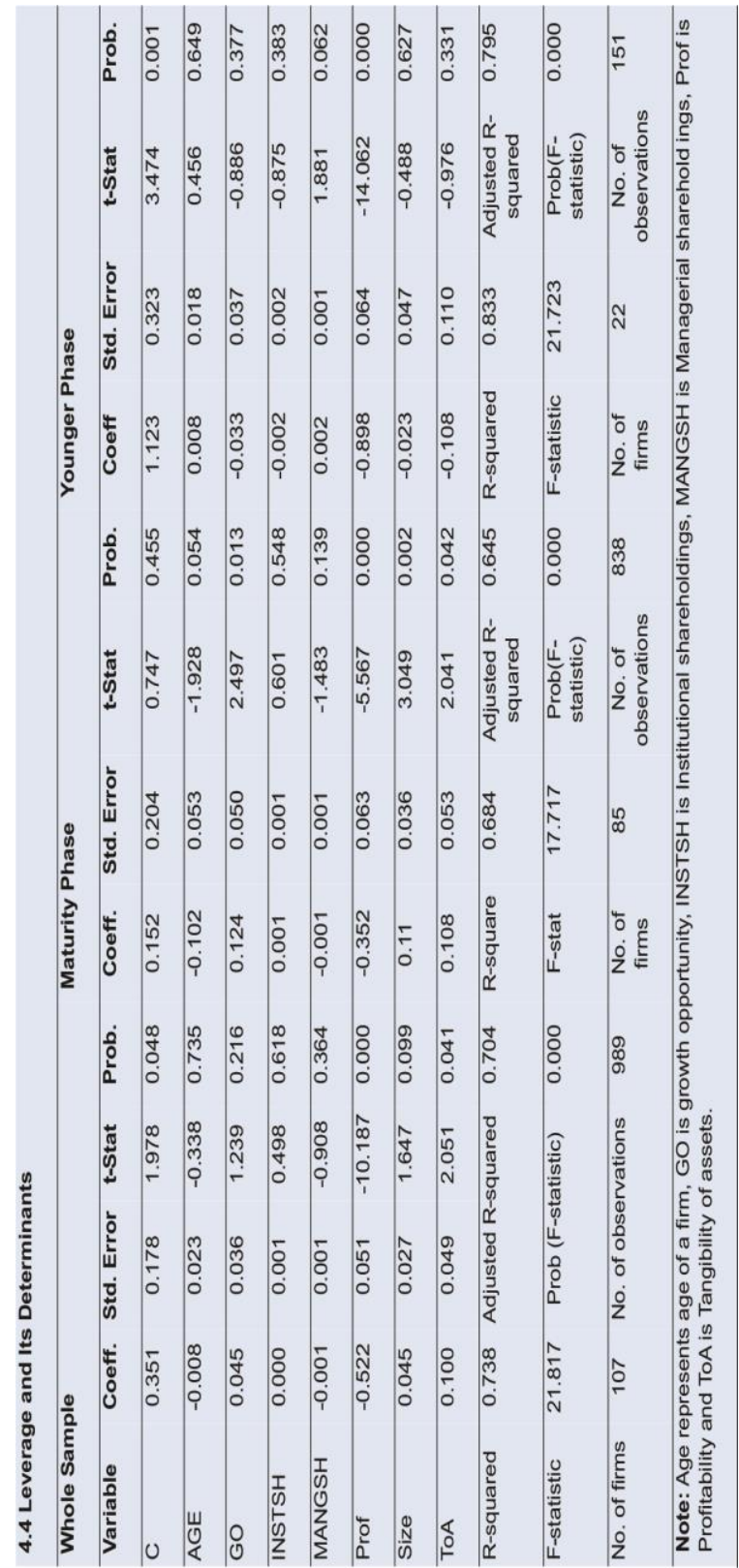

Size also being an important determinant of capital structure affects the leverage ratio positively. The size of a firm shows a positive relation with leverage highlighting the fact that as the size of firm increases, the firms are able to incorporate more loans into their capital structure. The firm can rebalance their structure and debt ratio decreases. The results are in accordance with Hassan and Butt (2009) and this increase is statistically significant. The tangibility of assets refers to the assets that are fixed and can be collateralized by the firm to obtain debt. When the ratio of tangible assets increases, the firm holds more capacity to incorporate debt into their capital structure by collateralizing those assets at the time of need for generating the finance. Therefore; the leverage ratio increases and a positive relation is observed, as previously studied by Michaelas et al. (1999) and Hall et al. (2004), and this relation is statistically significant.

Leverage shows a negative relation with age in a mature phase. This relation is statistically significant and in accordance with the Robb (2002). Growth opportunity 
shows a significant and positive relation with the firms that are in their maturity stage of their life cycle. The positive and significant results are previously found by Rocca and Rocca (2009). Ownership structure is statistically insignificant in the maturity stage of their life cycle. While taking into consideration the institutional shareholdings, the results are in line with Hassan and Butt (2009). Larger shares holding by institutions help the firm in obtaining the long term loan at an advantageous cost. Moreover, they also act as monitoring device over the strategic decisions of the company. Therefore, a positive relation is observed. Brailsford (2002) also provided the negative relationship between managerial shareholdings and the leverage levels. He discovered that lower the managerial shareholding, lower will be the agency conflicts and higher will be the debt ratio. On contrary to this, higher the shareholding for the managers leads to lower level of debt due to the probability of default. Profitability is also a significant determinant of leverage. The relation was hypothesized based on the study of Myers and Majluf (1984); according to them, the profitable firms have low debt level because they prefer internally generated funds over external funds. Therefore a negative relation is hypothesized. A study in Pakistani non-financial sectors also proves the existence of pecking order theory in the maturity stage of firms that the firms are more profitable due to earned reputation over years and they have established themselves. Therefore, as the earnings exceed, the level of debt decreases allowing themselves to rebalance the debt. These results are also in accordance with the Chittenden et al. (1996) and Jordan et al. (1998). Size and tangible assets go in the same line for the case of leverage; reason being that the increase in size and tangible assets allow the firm to incorporate more debt into their structure. Tangible assets show a significant positive relation with debt in case of older firms that seems to be more dependent upon the collateralizing assets for obtaining loans. Size also shows a significant positive relation for mature firms (Hall et al., 2004; Michaelas et al., 1999).

Age is positively related to leverage in younger firms but the result is insignificant. Moreover, the firms in the early 16 years of development have a negative relation between leverage and growth opportunities which states that as the growth opportunity is more in their early stages, the firms tends to decrease their leverage ratio. The reason might be the fact that younger firms are more inclined towards debt so as their 
growth opportunity increases, the leverage ratio decreases. Managerial shareholdings show a significant positive relation and institutional shareholdings show an insignificant negative relation. Moreover; in the introductory phase, profitability shows a significant negative relation with respect to debt ratio of a firm. Size and ToA show a negative relation with leverage. However; both the relations are statistically insignificant.

The above results can indicate that the results for the younger phase show some deviation from expected results as shown in the maturity phase. These deviating results are due to the smaller sample and fewer firms. The number of firms that fall in this category is relatively few in comparison to the mature firms. We have taken those firms that are listed on the KSE for the last sixteen years. The availability of data is also a problem for this phase. Moreover; there is no evidence available in the current situation for the younger phase in Pakistani Non-financial sector.

It is also interesting to test the presence of homogeneity effect in the sample for various industries. Table 4.5 represents the financial pattern of growth across different industries. The results depict that for almost all industries, the relation is significant for age and leverage except for engineering sector. Moreover, all the industries show a negative relation between age and leverage indicating that older firms have a lower level of debt.

Table 4.5: Sector-wise Regression Results

\begin{tabular}{ccccccccc}
\hline & & Energy & Chemicals & Engineering & General & Food & Textile & Misc \\
\hline \multirow{2}{*}{ AGE } & Co-efficient & -0.138 & -0.097 & -0.007 & -0.061 & -0.107 & -0.081 & -0.153 \\
\cline { 2 - 8 } & p-value & 0.003 & 0.000 & 0.760 & 0.001 & 0.000 & 0.000 & 0.010 \\
\hline \multirow{2}{*}{ GO } & Co-efficient & 0.365 & 0.209 & 0.006 & 0.087 & 0.220 & -0.836 & 0.072 \\
\cline { 2 - 8 } & p-value & 0.000 & 0.004 & 0.926 & 0.023 & 0.001 & 0.000 & 0.476 \\
\hline \multirow{2}{*}{ INSTSH } & Co-efficient & 0.002 & 0.001 & 0.000 & -0.003 & 0.006 & -0.003 & -0.003 \\
\cline { 2 - 8 } & p-value & 0.255 & 0.712 & 0.735 & 0.003 & 0.001 & 0.083 & 0.308 \\
\hline \multirow{2}{*}{ MANGSH } & Co-efficient & -0.001 & 0.001 & 0.000 & 0.002 & 0.004 & 0.000 & 0.005 \\
\cline { 2 - 8 } & p-value & 0.623 & 0.534 & 0.881 & 0.003 & 0.006 & 0.599 & 0.064 \\
\hline \multirow{2}{*}{ Prof } & Co-efficient & -0.070 & -0.246 & -0.434 & -0.637 & -0.552 & -1.042 & 0.099 \\
\cline { 2 - 8 } & p-value & 0.737 & 0.035 & 0.001 & 0.000 & 0.000 & 0.000 & 0.683 \\
\hline \multirow{2}{*}{ SIZE } & Co-efficient & -0.094 & 0.064 & 0.007 & -0.021 & 0.106 & 0.091 & 0.390 \\
\cline { 2 - 8 } & p-value & 0.150 & 0.004 & 0.829 & 0.458 & 0.014 & 0.020 & 0.000 \\
\hline \multirow{2}{*}{ ToA } & Co-efficient & -0.410 & 0.425 & -0.133 & 0.111 & -0.160 & 0.142 & 0.006 \\
\cline { 2 - 8 } & p-value & 0.003 & 0.000 & 0.100 & 0.110 & 0.100 & 0.072 & 0.980 \\
\hline R-squared & & 0.198 & 0.590 & 0.084 & 0.260 & 0.428 & 0.512 & 0.448 \\
\hline no. of obs. & 140 & 140 & 177 & 208 & 124 & 155 & 45 \\
\hline
\end{tabular}


Note: Age represents the age of a firm, GO is a growth opportunity, INSTSH is Institutional shareholdings, MANGSH is Managerial shareholdings, Prof is Profitability and ToA is Tangibility of assets.

\section{CONCLUSION}

A firm enters into the market with all the available finance that might include finance from family, relatives, friends or loan form institutions. The birth phase is the most critical time in the lifetime of a firm because the firm has to pay attention to several facets for competing in the market. The firm is new with no or little reputation, customers are fewer and a firm has to prove itself in various dimensions. For this purpose, it strives for the loan from the market, as financing is an essential ingredient for smooth running at this stage. Moreover, internal resources are not adequate to finance a young business. Therefore; the newly-formed and young firm needs an external financing to be their first option. This has rejected the proposed hypothesis that leverage increases with age; rather the reverse is being found in Pakistani non-financial sector.

As the time passes, the various facets become clearer and firm focuses on the key areas that help them to sustain in the market. The basic purpose of business is fulfilled i.e. profits and increased earnings facilitate firms to reinvest in different projects either for diversification, expansion or revival. These projects are financed by internal funding and requirement for external loans is lessened. Size, tangible assets, shareholdings are more emphasized upon in maturity stage. Thus, the previously taken debt in the younger stage is also balanced in this stage and lower amount of debt is seen in older firms. Therefore, we can suggest from the results that the younger firms use more debt and as the firm moves towards the maturity phase, the debt level is lowered by rebalancing their capital structure. This also provides evidence in support of the proposed hypothesis that the capital structure determinants vary across stages as they progress through different phases of their life cycle.

Another dimension of this study covers the financial pattern of different industries. The results indicate that the age is a relevant factor for all industries and this relation is significant. Thus for the non-financial sector, all industries follow a similar pattern in relation to age and leverage i.e. significant and negative. Moreover, the 
potential drivers vary across industries that affect the Capital Structure Decision of a firm. Results are shown in table 4.5 that are in support of hypothesis 3 that CS determinants vary across industries.

Further, we concluded that younger firms depend upon external financing independently of industry effects while mature firms have retained earnings to finance their projects. The potential determinants of CSD vary across stages. The significant difference across industries indicates that CSD also depends upon the inter-industrial characteristics.

\section{REFERENCES}

Anthony, J. H, and K. Ramesh. 1992. "Association between Accounting Performance Measures and Stock Prices", Journal of Accounting and Economics. 203-227.

Berger, A. N., and G. F. Udell. 1998. The Economics of Small Business Finance: The Roles of Private Equity and Debt Markets in the Financial Growth Cycle. Journal of Banking and Finance., 22.

Bulan, L., and Z. Yan. 2009. The Pecking Order Theory and the Firm's Life Cycle.

Carey, M., S. Prowse, J. Rea and G. Udell. 1993. The economics of Private Placements: A new look. Financial Markets, Institutions and Instruments., 8(2): 1-67.

Cassar, G. and S. Holmes. 2003. Capital structure and financing of SMEs: Australian evidence. Accounting and Finance. 43(2): 123-147.

Chen, J. and R. Strange. 2006. The Determinants of Capital Structure: Evidence from Chinese Listed Companies. Economic Change and Restructuring, 11-35.

Chittenden, F., G. Hall and P. Hutchinson. 1996. Small firm growth, access to capital markets and financial structure: Review of issues and an empirical investigation. Small Business Economics. 8(1): $59-67$.

Dickinson, V. 2005. Firm Life Cycle and Future Profitability and Growth. Working paper, School of Business, University of Wisconsin - Madison.

Evans, D. S. 1987. The Relationship Between Firms Growth, Size and Age: Estimates for 100 Manufacturing Industries. The Journal Of Industrial Economics., 35(4): 567-581.

Farooq, A., A. J. Ahsan, K. B. Umer, A. Irum and M. Latif. 2013. The impact of Capital Structure on Investment Behaviour and Performance of Firms in Pakistan.Business and Management Quarterly Review., 4(2): 36-43.

Gregory, B., M. Rutherford, S. Oswald, and L. Gardiner. (2005). an empirical investigation of the growth cycle theory of small firm financing. Journal of Small Business Management. 43(4): 382-392.

Hassan, A. and S. A. Butt. 2009. The impact of Ownership Structure and Corporate Governance on Capital Structure of Pakistani Listed Companies. International Journal of Business and Management., 4(2).

Helwege, J. and N. Liang. 1996. Is there a Pecking Order? Evidence from a panel of IPO firms. Journal of Financial Economics., 40(3): 429-458.

Jordan, J., J. Lowe and P. Taylor. 1998. Strategy and financial policy in UK small firms. Journal of Business Finance \& Accounting., 25(0.5): 1-27.

Michaelas, N., F. Chittenden and P. Poutziouris. 1999. Financial Policy and Capital Structure Choice in U.K. 
SMEs: Empirical Evidence from Company Panel Data. Small Business Economics., 12: 113130.

Miller, D. and P. H. Friesen. 1984. A Longitudinal Study of the Corporate Life Cycle. Management Science., 30(10): 1161-1183.

Modigliani, F. and M. Miller. 1958. The Cost of Capital, Corporation Finance, and the Theory of Investment, American Economic Review. 48: 261-297.

Myers, S. and N. Majluf. 1984. Financing Decisions When Firms Have Information that Investors Do Not Have, Journal of Financial Economics. 13: 187-221.

Quinn, R. E., and K. Cameron. 1983. Organizational Life Cycles and Shifting Criteria of Effectiveness: Some Preliminary Evidence. Management Science. 29(1): 33-51.

Rajan, R. G., and L. Zingales. 1995. What Do We Know about Capital Structure? Some Evidence from International Data. The Journal of Finance., 50(5): $\quad$ 1421-1460.

Rocca, M. L., and T. L. Rocca. 2009. Capital Structure Decisions During a Firm's Life Cycle. Small Bus Econ., 107-130.

Romano, A. Claudio., A. George, Tanewski and Kosmas X. Smyrnios. 2001. Capital structure decisionmaking: A model for family business. Journal of Business Venture. 16 (3): 285-310

Walker, D. A. 1989. Financing the Small Firm. Small Business Economics., 1(4): 285-296.

Williams, D. A. 2010. An Empirical Investigation into the Financing of Small, Family-owned Businesses in Jamaica. Social and Economic Studies., 59(3), Special Focus on Womenand Family-Owned Businesses in the Caribbean, 31-57.

Yan, Z. 2006. A new methodology of measuring corporate life-cycle stages.

HYPERLINK"http://www.kse.com.pk/" http://www.kse.com.pk/

\section{APPENDIX}

Table 4.7: Panel Data Results

1)

\begin{tabular}{|c|c|c|c|c|c|c|c|c|c|}
\hline \multicolumn{5}{|c|}{ FIXED EFFECTS } & \multicolumn{5}{|c|}{ RANDOM EFFECTS } \\
\hline Variables & Coefficient & St.Error & T.Stat & Prob & Variables & Coefficient & St.Error & T.Stat & Prob \\
\hline $\mathrm{C}$ & 0.295 & 0.201 & 1.468 & 0.143 & $\mathrm{C}$ & 0.452 & 0.137 & 3.295 & 0.001 \\
\hline AGE & -0.009 & 0.015 & -0.607 & 0.544 & AGE & 0.012 & 0.039 & 0.301 & 0.764 \\
\hline GO & 0.040 & 0.037 & 1.094 & 0.274 & GO & 0.020 & 0.029 & 0.685 & 0.493 \\
\hline Prof & -0.524 & 0.051 & -10.200 & 0.000 & Prof & -0.582 & 0.050 & -11.703 & 0.000 \\
\hline Size & 0.055 & 0.032 & 1.718 & 0.086 & Size & 0.054 & 0.019 & 2.898 & 0.004 \\
\hline ToA & 0.096 & 0.049 & 1.954 & 0.051 & ToA & 0.054 & 0.041 & 1.312 & 0.190 \\
\hline INSTSH & 0.000 & 0.001 & 0.388 & 0.698 & INSTSH & 0.001 & 0.001 & -0.688 & 0.491 \\
\hline MANSH & -0.001 & 0.001 & -0.941 & -0.347 & MANSH & 0.001 & 0.001 & 0.741 & 0.459 \\
\hline \multicolumn{2}{|c|}{ R-Squared } & \multicolumn{3}{|c|}{0.738} & \multicolumn{2}{|c|}{ R-Squared } & \multicolumn{3}{|c|}{0.155} \\
\hline \multicolumn{2}{|c|}{ Adjusted R-Squared } & \multicolumn{3}{|c|}{0.704} & \multicolumn{2}{|c|}{ Adjusted R-Squared } & \multicolumn{3}{|c|}{0.149} \\
\hline \multicolumn{2}{|c|}{ F-statistic } & \multicolumn{3}{|c|}{21.614} & \multicolumn{2}{|c|}{ F-statistic } & \multicolumn{3}{|c|}{25.699} \\
\hline \multicolumn{2}{|c|}{ Prob (F-statistic) } & \multicolumn{3}{|c|}{0.000} & \multicolumn{2}{|c|}{ Prob (F-statistic) } & \multicolumn{3}{|c|}{0.000} \\
\hline
\end{tabular}

2)

\begin{tabular}{|c|c|c|c|}
\hline \multicolumn{4}{|c|}{ Correlated Random Effects-Hausman Test } \\
\hline Test Summary & Chi. Sq. Statistic & Chi. Sq. D.f & Prob \\
\hline Cross-section Random & 30.594 & 8 & 0.0002 \\
\hline
\end{tabular}

